\title{
Contested Meanings of Norms: A Research Framework
}

\author{
Antje Wiener \\ Professor of Politics and International Studies, Department of European Studies and Modern \\ Languages, University of Bath, Bath BA2 7AY, UK. \\ E-mail: aw309@bath.ac.uk
}

Constitutionalism is 'a legal limitation on government' and 'an antithesis of arbitrary rule.' It is this aspect of constitutionalism which the contributions to this special issue discuss with reference to various forms of governance beyond the state. It focuses on accommodating cultural diversity within the constitutional framework of one State (e.g. Canada) and on addressing recognition in a constitutional framework beyond the State (e.g. the European Union, the United Nations, or, the World Trade Organization). Once constitutional norms are dealt with outside their sociocultural context of origin, a potentially conflictive situation emerges based on de-linking two sets of social practices (i.e. cultural and organizational practices). The article argues that the potential for conflict caused by moving fundamental norms such as human rights, citizenship, sovereignty or the rule of law outside the bounded territory of states a decoupling of the customary from the organizational occurs, which creates a situation of enhanced contestedness. That is, through this transfer between contexts the meaning of norms becomes contested - as differently socialized individuals (politicians, civil servants, NGO activitis, parliamentarians or lawyers trained in different legal traditions) seek to interpret them. That is, while in supranational contexts actors may agree on the validity of a particular norm, say for example human rights, that agreement may not be recognised outside these limited negotiating contexts. Subsequently, associative connotations with normative meaning is likely to differ according to experience with norm-use. It is therefore important to 'recover' the hidden interrelation between cultural and organizational practices. Both contribute to the interpretation of meanings that are entailed in fundamental norms which are, in turn, constitutive for democratic governance beyond the state. Comparative European Politics (2007) 5, 1-17. doi:10.1057/palgrave.cep.6110107

Keywords: norms; democratic governance; constitutionalism; methodology

\section{Introduction}

The contributions to this special issue discuss the role of different norm types including fundamental norms, organizing principles, and standardized procedures, in contexts of governance beyond the state. More specifically, 
the authors examine organizing principles such as accountability, the democratic audit, transparency and fundamental norms such as access to contestation, citizenship, and representation in different policy sectors of nonstate governance ${ }^{1}$. They reveal a considerable degree of contestation regarding the meaning of norms and their interpretation not only according to the context of norm implementation, that is, in different policy sectors (Begg, 2007, 36; Puetter, 2007, 18; Jenson, 2007, 53; Puntscher-Riekmann, 2007, 121), but also in contexts of theory generation, that is, in different academic contexts (Bovens, 2007, 104; Pollack, 2007, 87; Lord, 2007, 70). The findings are of particular relevance to the compliance literature and the governance literature, which has so far predominantly worked with a behavioural perspective examining the implementation of or reaction to norms as structural variables by more or less well performing norm followers. In turn, we argue that the relational perspective of contestation as constitutive for the normative structure of politics has received comparatively less attention.

In light of moving processes, practices, and principles of governance out of the modern state context, the contested quality of normative meaning is enhanced and differences in the interpretation of norms and their meanings are expected as a rule rather than as an exception. In sum, under conditions of transnationalization the regulatory practices of modern constitutionalism are increasingly moved out of the social contexts of their modern i.e. Hegelian conception. Subsequently, interpretation of the principles and norms of governance depends increasingly on cultural practices. That is, inasmuch as the 'stable certainties of the constitutional settlement derived from the peace of Westphalia' (Everson, 2004, 125) are undermined, the contingency of cultural practices gains analytical importance.

It is therefore argued that individually held associative connotations are central to studying contestation of normative meanings beyond the state. This special issue's discussion of contested meanings offers new insights into the challenge of governance beyond the state — and beyond Europe. In the following, this article presents a framework for research on the contested meanings of different norm types in qualitative studies of governance beyond the state. The first section summarizes the certainties of modern constitutionalism that are challenged in contexts where the norms of constitutionalism are applied in context beyond the state. The second section focuses on the role and type of norms and conditions under which normative meaning is contested. The third section focuses on the application of this research framework in particular case studies. The final section concludes with research assumptions.

\section{Constitutionalism Beyond the State}

Modern constitutionalism entails the three central elements of limited government, adhering to the rule of law and protecting fundamental human 
rights. These elements are to be set in place and kept functioning by a constitution whether this is a written or an un-written document. In addition, it builds on two types of identities, that are related to the central rights entailed in a constitution. The first type of identity is derived from the shared recognition of the type of rights that stand to be defended and protected by the constitution. The second identity builds, more directly, on the notion of 'each member of a society as a bearer of the same constitutional rights.' It is 'highly unlikely that specific constitutional structures and provisions could successfully survive wholesale transplantation from one country to another.' Nonetheless, modern constitutionalism 'does impose certain definite broad requirements such as limited government, adherence to the rule of law, protection of fundamental interests, and compliance with the demands of abstract equality.' (Rosenfeld, 1994, 6, 14, respectively). The constitutional doctrines of liberalism and republicanism, which have been forged in the 18th century, assign three functions to a modern constitution, that is, it 'constitutes a political entity, establishes its fundamental structure, and defines the limits within which power can be exercised politically' (Castiglione, 1996, 9-10). In sum, a constitution identifies fundamental norms. It 'denotes a body of meta-norms, rules that specify how legal norms are to be produced, applied, and interpreted' (Stone, 1994, 4).

While throughout the 19th and 20th centuries constitutionalism became conceptually linked with modern nation-states, the extended application of constitutionalism beyond the state in the late 20th century and now the 21 st century has added a new dimension to familiar modern constitutional choices. According to these, constitutionalism is 'a legal limitation on government; it is an antithesis of arbitrary rule' (McIlwain, 1939, 21, cf. Fellman, 2005, 1). These two characteristics, the legal limitation of government and the antithesis of arbitrary rule, are better known as democracy and the rule of law as the two core principles of democratic constitutionalism (Tully, 2002). These two principles of constitutionalism transcend historical contingent polity formations and are applicable as a yardstick to any kind of contemporary constitutional arrangement. This take on constitutionalism includes both studies that focus on accommodating cultural diversity within the constitutional framework of one State (e.g. Canada) and addressing recognition in a constitutional framework beyond the State (European Union or the World Trade Organization) (Weiler, 2002; Weiler, 1999; De Burca and Scott, 2003). That is, in addition to the vertical time axis, for example, reconstructing constitutional dialogues over time (Tully, 1995), a horizontal space axis comparing policy sectors, polities, or, indeed academic debates, requires analytical attention.

Once constitutional norms are dealt with outside their socio-cultural context of origin, a potentially conflictive situation emerges. The conflict is based on 
de-linking the two sets of social practices that form the agreed-upon political aspect, on the one hand, and the evolving customary aspect of a constitution, on the other. The potential for conflict caused by moving constitutional norms outside the bounded territory of modern states, that is, outside the domestic polity and away from the inevitable link with methodological nationalism, lies in the decoupling of the customary from the organizational dimension of the nomos (Tully, 1995; Wiener, 2006a). The contestation of normative meaning is enhanced through this transfer between contexts. It is empirically accessible by examining the individually held associative connotations of differently socialized actors such as politicians, civil servants, parliamentarians, or lawyers trained in different legal traditions seek to interpret the norms they encounter in a transnational environment. In other words, while in supranational contexts actors might well agree on the importance of a particular norm, say for example human rights matter, the agreement about a type of norm does not allow for conclusions about the meaning of norms. In different domestic contexts that meaning is likely to differ according to experience with 'norm-use' (Kratochwil, 1989, 18; Dworkin, 1978). It is therefore important to recover the interrelation between the two types of social practices, that is, the cultural practices that generate the customary, on the one hand, and organizational practices facilitated by public performance that interprets the norm for political and legal use, on the other. Both are necessary in order to assess and examine the interpretation of meanings that are entailed in constitutional norms.

Given the likelihood of contestation, agreements on the rules, principles, and procedures of democratic constitutionalism in beyond the state contexts depend on dialogue (see e.g. Puetter, 2007, 18). In other words, to agree on transnationalized principles of constitutionalism, for example in the European Union or other multinational political contexts, requires awareness of multiplicity in meaning and, subsequently, mechanisms which allow for ongoing exchange about the multiple meanings of norms. This awareness depends on the proper analytical tools to capture how the complex interplay between the customary and the organizational dimension of constitutionalism is linked. Working with the generally accepted definition of institutions as 'formal and informal procedures, routines, norms and conventions embedded in the organizational structure of the polity or political economy' (Hall and Taylor, 1996, 938), it possible to reflect the input of the dual challenge of accommodating the diversity of normative meanings within modern constitutional frameworks that are, in addition, moved outside the territorial boundaries of modern states.

It is suggested that the changes brought about by the transnationalization of politics and policy stress the analytical role of individually held connotations as influential for the assessment of conflict and/or legitimacy as potential outcomes of contestation. In the social environment created by the 
transnationalization of particular political arenas in relation with expanding policy sectors such as say enlargement, monetary policy, financial policy, the environment, and, more recently foreign and security policy, it is important to identify group-based associative connotations that allow an understanding of the respective normative 'structure of meaning in use' (Weldes and Saco, 1996; Milliken, 1999).

\section{Norms}

Norms may entail validity via a legal framework that stipulates them (constitution, treaty) and have achieved social facticity (appearing as appropriate to a group). Yet, successful norm diffusion ultimately depends on the additional third category of cultural validation. The research on norm contestation contributes to the literature on the dynamic of norms and its impact on the potential of conflict and the possibility of legitimate order in world politics. Based on an interpretative approach to the social sciences, it is reflexive, relational, and historical (Giddens, 1979; Tilly, 1975; Somers, 1994). A main consideration for a research framework that allows comparative studies of normative meanings lies with the more or less consequent application of the contingency imperative of norms as socially constructed. That is, to be able to grasp norms as a contested political resource under conditions of transnationalization, we need to understand how and where they are situated. As James Tully contends,

[W] hat we need in order to be both critical and effective is not an account of norm creation for some ideal game [e.g. governance beyond the state, AW], but an account of the possibility of democratic norm creation under the conditions of the field in which we find ourselves here and now (Tully, 2002, 19).

To tackle these conditions Anthony Giddens' seminal observation of the duality of structures presents a key analytical cue with a view to situating normative meaning when he points out

[B]y its recursive nature I mean that the structured properties of social activity - via the dual quality of structure - are constantly recreated out of the very resources which constitute them (Giddens, 1984, emphasis added $\mathrm{AW}$ ).

In pursuing both an empirical and a normative goal, this special issue addresses two dimensions. One dimension refers to conflictive decisions as the outcome of international negotiations; the other addresses the normative assumption of a 'good' post-state political order. We advocate extending the analysis of the role of norms from understanding their stable dimension as a 
social institution towards theorizing their dynamic dimension as a flexible social construct. It is therefore appropriate to examine the role of 'contestation' as an intervening variable by proposing to centre research either - more pragmatically - on the debate about procedural and institutional changes, or on the possibilities of enhancing democratic legitimacy based on access to contestation and mutual recognition. While this notion builds on Robert Dahl's erstwhile observation on measuring a democratic system's inclusiveness based on access to participation 'in the system of public contestation' (Dahl, 1971, 4), it considers the republican understanding of ongoing 'democratic communicative action' as a necessary condition for norms, rules and principles to be considered as appropriate and legitimate (Tully, 2002, 20-22). If democratic processes require contestation as a necessary element in order to generate and maintain legitimacy of legal norms, contestation needs to be integrated in supranational institutional settings as a common procedure.

\section{Contested Meanings}

As the rule always lies in the practice (Taylor, 1993, 50), any work on norms will proceed from the premise that norms - and their meanings - evolve through interaction in context. Norms are therefore contested by default. This is particularly important in beyond-the-state contexts where "no "categorical imperatives" are in practice', and where 'the context, or situation, within which activities take place is extremely important' (Jackson, 2005, 19-20). While norms may acquire stability over extended periods of time, they remain flexible by definition. Dialogue thus plays a key role both in revealing normative meanings and in keeping them at bay based on the application of the two core constitutional principles (see e.g. Puetter, 2007, 18). We can therefore hypothesize that the contested meaning of norms is enhanced under three conditions. ${ }^{2}$ First, a situation of crisis raises stakes for understanding meanings based on social institutions, the social feedback factor is reduced. Second, the change of governance processes, that is, the extension of governance practices beyond modern political and societal boundaries changes the social environment and hence the reference frame of social institutions; the social feedback factor is reduced. And thirdly, the historical contingency of normative meaning indicates a change of constitutive social practices both cultural and organizational, and hence normative meaning over time (see Box 1).

The case studies focus primarily on the third condition in particular and explore the impact of changing governance processes beyond the limits of modern state boundaries. This condition indicates a transfer of normative meanings outside the familiar - domestic - community of interpretation. The recognition of norms is culturally based, insofar, as it is sustained by the meaning ascribed to norms through discursive practices. As discursive 
Box 1 Enhanced contestation of norms: three conditions

No. Condition

1 The historical contingency of normative meaning indicates a change of constitutive social practices - both cultural and organizational - over time; normative meaning changes over time. Condition one is the most encompassing one.

2 A situation of crisis raises stakes for understanding meanings based on social institutions, the social feedback factor is reduced.

3 The change of governance processes, that is, extension of governance practices beyond modern political and societal boundaries, changes the social environment and hence the reference frame of social institutions; the social feedback factor is reduced.

interventions, these practices are related to societal institutions (appropriateness), on the one hand, and associative connotations (recognition based on cultural practices), on the other. The transnationalization of political processes and policies indicates a change of both the constitutional framework (legal validity) and the social environment (appropriateness; social facticity). In the absence of these two factors, it is individually held associative connotations that make or break the successful work of norms.

Research on norms therefore needs to address the conflicting normative substance of resources, which emerge and are firmly rooted in specific political arenas of domestic politics or international organizations. We know equally little about the emergence of common substance of resources, which are generated in transnational arenas. Yet, diverging interpretations of meaning may induce a clash of normative resources and hence potentially present a source of conflict for politics beyond the state. Its importance increases as globalization and transnationalization proceed to expand. We can therefore hypothesize more generally that the more transnational a context of interaction, the more likely are encounters among bearers of different culturally and socially generated resources. Whether or not this conflict of meanings turns into international political conflict or, whether it may be turned into an innovative contribution to enhance institutional legitimacy in transnationalized politics depends on a number of factors. While interest (consequentialism) and identity (appropriateness) are two of them, connotative meaning (contestedness) is a third, largely under-researched factor.

\section{Types of Norms}

For analytical reasons, a distinction among three types of norms including fundamental norms, organizing principles, and standardized procedures is proposed (see Box 2). ${ }^{3}$ These three different types of norms are distinguished 
Box 2 Types of norms

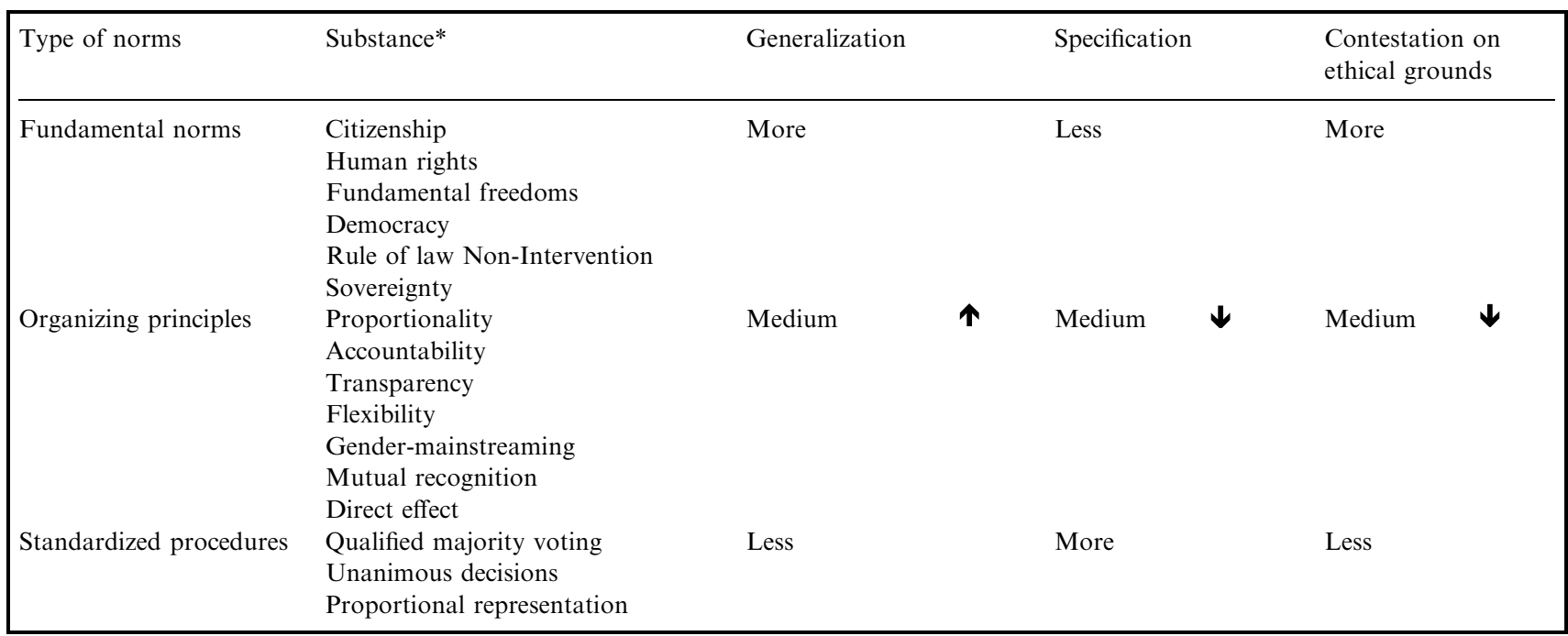

*Note that these column's entries are not meant to be exclusive, but list examples of each type of norm. 
according to their respective degree of generalization and specification as well as with regard to their moral and ethical scope. Accordingly, the first type, that is, fundamental norms includes both 'core constitutional norms' that are most commonly used with reference to nation-state constitutions (Rosenfeld, 1994) as well as 'basic procedural norms' that are most commonly applied in international relations theory (Jackson, 2005). ${ }^{4}$ They include citizenship, human rights, the rule of law, democracy as well as non-intervention, abstinence from torture and so forth. Second, organizing principles evolve through policy or political processes. They inform political procedures and guide policy practices and include such principles such as legality, accountability, transparency, legitimacy, and gender-mainstreaming. Third, standardized procedures such as rules and provisions are the least likely to be contested on moral or ethical grounds as they entail prescriptions for action, which are not-contingent and as specified as possible such as the instructions to assemble a flat-pack piece of furniture or a shelve (Kratochwil, 1989) or guidelines pertaining to electoral processes, for example, qualified majority voting.

Fundamental norms keep a community together. They are generally linked with the polity level. With reference to modern nation-states they are known as core constitutional norms such as the rule of law, fundamental freedoms and human rights, democracy and equal citizenship and with reference to world politics, they are defined as 'basic procedural norms' including sovereign equality, respect for human rights, and non-intervention in international affairs among others (Jackson, 2005, 16-17). Organizing principles structure the behaviour of individuals or groups. They evolve through the process of politics and policymaking and include such norms as accountability, transparency, gender-mainstreaming, peacekeeping or peace enforcement (Bovens, 2007, 104, Jackson, 2005). Finally, standardized procedures entail detailed and clearly articulated advice for specific activities such as, for example, a manual accompanying a flat-packed set of shelves (see Kratochwil, 1989). It follows logically that the most contested norms are the least specific, that is, the fundamental norms, while the least contested are the most specific, that is, the standardized procedures. Organizing principles may be contested, they may also be 'upgraded' towards fundamental norms, for example, the principle of mutual recognition may be understood as an organizing principle with reference to one particular policy process in one policy, yet it may well be a core constitutional norm in another.

Since ' $[\mathrm{N}]$ o rules in international law are absolute', indeed, ' $[\mathrm{N}]$ othing in this normative sphere is absolute' (Jackson, 2005, 19), the expectation among international lawyers is that the substance of law depend on input through legal discourse, that is, deliberation, jurisprudence, learned opinion, and other discursive interventions. The contested issue regarding the crucial input of 
discourse in international law lies in different legal traditions. These can generally be distinguished according to a stronger disposition to interpret the letter of the law among continental lawyers, on the one hand, and, a disposition towards a generally flexible quality of international law understood as evolving through the process of jurisprudence among AngloSaxon lawyers, on the other (De Burca and Scott, 2003). Nonetheless it can be argued that while considering the input of discourse at different stages, lawyers would attribute a strong and constitutive role to discursive interventions in the process of international law (Keohane, 1997; Brunnée and Toope, 2000).

That emphasis on discourse as constitutive towards establishing substantive meaning of norms is not necessarily shared among political scientists who make conceptual distinctions between arguing (Risse, 2000), contestation (Dahl, 1971), deliberation (Cohen, 1997; Joerges and Neyer, 1997), and discursive interventions (Weldes and Saco, 1996; Milliken, 1999). In international relations theory, the most distinctive input into the role of language as an intersubjective element in the process of the construction of norms was introduced by regime theory. In particular, Kratochwil and Ruggie's (1986) intervention in this debate singled out a constructive as opposed to a behavioural approach to discourse as intervening in politics based on the generation of substantive meaning rather than merely studying behavioural reactions to the norms, rules, and beliefs that emerged in the environment of supranational regimes.

\section{Bringing Culture Back In}

The transnationalization of political processes and policies indicates a change of the constitutional framework (legal validity) as well as the social environment (social facticity) in which politics takes place. Transnationalization raises the 'community problem,' which has become so adamant for students of European integration. Two insights from recent scholarship on the EU's constitutional process or project illustrate the problem. The first calls for a constitution, arguing,

[T] he more diverse the society, the more important [it is] to have a constitution delineating authority, power, responsibilities, rights and obligations, including guaranties for individuals and minorities (Olsen, $2005,8)$.

The second holds that in the absence of a community, a constitutional project is unlikely to succeed. As Bernhard Peters noted,

[I]n German debates over the European Union, in general, and its 'democratic deficit' in particular, the following quotation by Peter Graf 
Kielmansegg has become almost canonical: 'Europe, even limited to Western Europe, is not a community of communications, barely a community of members, and only a very limited community of experience' (Peters, 2005, 84).

That is, the 'community' condition is considered as both impossible and necessary for democratic governance in the EU's 'beyond the state' context (Weiler and Wind, 2003; Wobbe, 2003). If we follow Dewey's point on democracy as 'an ideal' which is based on the 'idea of community life' (Dewey, 1954, 14), then it is crucial to understand both the ideal and the day-to-day practice of democracy. A triangular interplay between the democratic ideal, the way it is practiced and experienced in different contexts, and the often contested (Gallie, 1956) expectations forged by these social practices comes into play. ${ }^{5}$ Studying the practices of democracy in different contexts and comparing them hence enables us to assess the different meanings of the concept of democracy as a set of norms, principles and procedures. This perspective suggests a comparison between the meaning of norms in contexts beyond the state and among different national contexts, each of which entails a particular variety of normative interpretations pending on cultural diversity (see e.g. multinational political contexts such as in the USA, Canada, Mexico, and so on). Both perspectives take the framework of modern constitutionalism as a reference frame for comparison.

With a view to uncover hidden meanings of norms, which have been produced through cultural practices in different contexts, I propose to work with a 'prospective' method of analysis. While Tully's research to recover hidden constitutional meanings in the context of the Canadian one-state employed a 'retrospective' method, beginning with a particular historical condition (inequality before the constitution according to cultural identity) and searching back for its causes, prospective analysis works with a view to the European beyond-the-state context begins with a particular historical condition (conflicting interpretations of constitutional meanings) and searching forward to the alternative outcomes of that condition with a specification of the paths leading to each of the outcomes. ${ }^{6}$ That is, further to the reconstruction of constitutional dialogues based on the empirical focus on two sets of practices (organizational and cultural) that contributed to construct the meaning of constitutional norms over time (ancient type of constitution), the beyond-the-state context requires the additional dimension of comparing political arenas. The comparative dimension facilitates the tools to observe changes in patterns of interpretation. As John Bendix notes,

comparative studies illuminate the meaning of sociological universals.' They allow us to question 'usual connotations' which may, for example are 
adopted into scholarly language from ordinary speech and seek to "make these connotations explicit (Bendix, 1963, 535).

The comparative research design which is proposed here takes account of contemporary constitutionalism with reference to emerging transnational political arenas, on the one hand, and enduring domestic arenas, on the other. The research assumption is based on the observation that once constitutional norms are dealt with outside their sociocultural context of origin, a situation of potential conflict emerges. The conflict follows the de-linking the two sets of social practices, which compose the organizational and the customary dimensions of a constitution. The potential for conflict caused by moving constitutional norms outside the domestic polity lies in the decoupling of the customary from the organizational. It is through this transfer between contexts, that the meaning of norms becomes contested as differently socialized actors, for example, politicians, civil servants, parliamentarians, or lawyers trained in different legal traditions seek to interpret them.

In other words, while in supranational contexts actors might well agree on the importance of a particular norm, say for example human rights matter, the agreement about a kind of norm does not allow for conclusions about the meaning of that very norm. As in different domestic contexts, that meaning is likely to differ according to experience with norm-use, it is important to recover the crucial interrelation between the social practices that generate meaning, on the one hand, and public performance that interprets the norm for political and legal use, on the other (Dworkin, 1978; Kratochwil, 1989). Both aspects of the nomos - the organizational and the customary - contribute to the interpretation of meanings that are entailed in constitutional norms.

Constitutional lawyers may argue that constitutional norms will take precedence over the procedures and rules that are applied to control and regulate politics. As long as the core role of a constitution is respected, the meaning is always subordinate to the type of a constitutional norm. In turn, from a political science perspective on the impact of rules and norms in world politics, we know that there is a strong social dimension to rule following. Socialization into a community, it has been argued, enhances the diffusion of norms, values and rules of that community towards all members (Schimmelfennig, 2000). However, as Tully has pointed out,

[A] constitution can seek to impose one cultural practice, one way of rule following, or it can recognise a diversity of cultural ways of being a citizen, but it cannot eliminate, overcome or transcend this cultural dimension of politics (Tully, 1995, 6; emphasis added).

Culture is hence a dimension in constitutional politics that does have an impact in one way or another. The challenge lies in the question of how to 
bring culture back into constitutionalism, that is, where to locate the cultural dimension analytically, and, how to study it empirically. It is crucial for constitutional analysis to identify indicators for diversity and commonality of meaning of constitutional norms at a level of desegregation that allows for the empirical assessment of meaning. Approaches that focus on different kinds of norms that is, human rights, minority, rights or other rather than on their respective meanings, cannot account for information regarding potential conflict and its resolution, nor can this offer an assessment of changes in the normative structure which guides politics at all times, be it within or beyond state boundaries.

\section{Conclusive Observations}

This research framework follows from two observations, one empirical and the other normative. The empirical observation holds that contestation is expected once norms are interpreted by individuals who do not share in continuous interaction (e.g. conflict emerges as a problem for both policy and politics). The normative observation maintains that if contestation is a necessary condition for norm validity, norms must in principle be contestable (e.g. legitimacy emerges as the key organizing principle which needs to be accommodated and warranted). These two observations are applicable to different types of political arenas including domestic, international, supranational, and transnational ones. Diversified governance then requires a turn to the increasingly mobile individual or micro-group as interpreter and negotiator of diversity. The meanings of norms, often with expressed or declared legal validity for these arenas, are interpreted through individual 'transnational mobility'. Importantly, the territory in which these individuals - usually elites, often however, advocacy groups and increasingly protesters - are characterized by 'a social reality of non-synchrony' (Eder, 2004, 99, 104). In this context, the major innovative moves by new institutionalists such as, for example, the focus on state-society relations in order to explain variation in state capacity in policy implementation (Skocpol, 1996, 61-62), or the role of ideas for policy process based on learning within a social environment (Hall, 1993) require a turn towards the individual as an interacting and mobile interpreter in a particular context. The link between individually held associative connotations and the role of norms as invisible yet constitutive resources in politics is elaborated according to the normative condition of legitimate and democratic governance.

This article's discussion sought to assess the concept of norms on a more general level and working with the 'consistent constructivist' assumption that, as social constructs, norms are contested by default (Fierke, 2006). Their contestation is enhanced under three conditions. These include, first, situations of crisis in which the process of interpretation based on social institutions is 
radically cut short. Secondly, contestation is enhanced under the condition of expanding governance processes beyond the boundaries of a particular community of interpretation. And thirdly, it is enhanced by the very condition of historical contingency of normative interpretation as such. The political role of constitutional norms and the interpretation of their meaning thus depend heavily on the social environment in which they are interpreted. For example, it has been demonstrated that while political ideas are spread across boundaries, they are interpreted anew and often quite differently pending on their new social environment of implementation (Hall, 1989; Jenson, 2005, www.qub. ac.uk/polproj/reneg/workshop.htm, accessed 20 October 2005).

The contributions to the special issue address conflictive meanings along three distinctive types of norms, which relate to three dimensions of the community. They include fundamental norms, organizing principles and standardized procedures. The individual contributions stress the importance of noting difference and establishing a typology for analysing accountability; accommodating difference with a view to policy coordination; identifying procedures and principles of democracy in the respective national and transnational political arenas; and establishing access to participation based on democratic citizenship practice. The goal is to take stock, compare (empirically, conceptually), and elaborate on new theoretical perspectives. The contributions address the issues of policy implementation, constitution making, and the normative conceptual debate about democracy. They raise questions of how and why norms work differently in different arenas; how to define norms, and how to guarantee democratic quality in beyond the state contexts. Accordingly, the emphasis is on analysing the quality of public deliberation, the degree of access to contestation, and the respective appropriate procedural arrangements. Thus, it is possible to tackle the input of contested meanings and subsequently assesses the possibilities for democracy beyond the state that stresses the role of new spaces that emerge in addition to the familiar modern spaces conceptualized as community, polity, or society.

\section{Notes}

1 This special issue draws on the workshop on 'Contested Meanings: Democratic Practice and Principles across Cultural Boundaries' held at Queen's university Belfast, 22-23 September 2005. Funding from the EU 6th Framework Network of Excellence CONNEX; the Jean Monnet Centre of Excellence at Queen's and the British Academy is gratefully acknowledged.

2 The following draws closely on Wiener (2006a, esp chapter 4).

3 Note a similar pattern of distinction by Dimitrova (2005) who distinguishes, however, between 'levels' not 'types' of norms.

4 I thank Martin Binder who raised this issue at a discussion at the Science Centre for Social Research in Berlin, 8 June 2006. 
5 This observation follows from discussions at the workshop which preceded this special issue, see: Contested Meanings: Democratic Practice and Principles across Cultural Boundaries, workshop held at the Queen's University of Belfast, 22-24 September 2005, sponsored by the EU Sixth Framework Programme's Network of Excellence, CONNEX, Working Group 2, Team A, the Jean Monnet Centre of Excellence at Queen's, the School of Management and Economics at Queen's as well as the British Academy's Visiting Professorship Programme. For the workshop programme see http://www.qub.ac.uk/schools/SchoolofPoliticsInternationalStudiesandPhilosophy /FileStore/PDFfiles/Filetoupload,16547,en.pdf $\langle 16$ May 2006〉.

6 For the distinction between retrospective and prospective methods of analysis see Tilly $(1975,14)$.

\section{References}

Begg, I. (2007) 'Contested meanings of transparency in central banking', Comparative European Politics 5(1): 1-16.

Bendix, R. (1963) 'Concepts and generalizations in comparative sociological studies', American Sociological Review 28(4): 532-539.

Bovens, M. (2007) 'New forms of accountability and EU-governance', Comparative European Politics 5(1): 104-120.

Brunnée, J. and Toope, S.J. (2000) 'International law and constructivism: elements of an interactional theory of international law', Columbia Journal of Transnational Law 39(19): 1-87, typescript vers.

Castiglione, D. (1996) 'The Political Theory of the Constitution', in R. Bellamy and D. Castiglione (eds.) Constitutionalism in Transformation: European and Theoretical Perspectives, Cambridge: Blackwell, pp. 6-23.

Cohen, J. (1997) 'Deliberation and Democratic Legitimacy', in Bohman, J.R.W. (Hrsg.) Deliberative Democracy. Essays on Reason and Politics, Cambridge, MA: Princeton University Press, pp. 67-91.

Dahl, R.A. (1971) Polyarchy. Participation and Opposition, New Haven and London: Yale University Press.

De Burca, G. and Scott, J. (eds.) (2003) The EU and the WTO: Legal and Constitutional Issues, Oxford: Hart Publishing.

Dewey, J. (1954) The Public and its Problems, Athens, OH: Swallow Press.

Dimitrova, A. (2005) 'The power of norms in transposition: norms and conditionality in Slovakia', in Paper presented at the workshop 'Contested Compliance in International Policy Coordination-Bridging Research on Norms and Policy Analysis', 17-18 December 2005; Portaferry, County Down, Northern Ireland.

Dworkin, R.M. (1978) Taking Rights Seriously, Cambridge, MA: Harvard University Press.

Eder, K. (2004) 'The two faces of Europeanization. Synchronizing a Europe moving at varying speeds', Time \& Society 13(1): 89-107.

Everson, M. (2004) 'Review article: accountability and law in Europe: towards a new public legal order?' Modern Law Review 67(1): 124-138.

Fellman, D. (2005) 'Constitutionalism' http://etext.lib.virginia.edu/cgi-local/DHI/dhi.cgi?id= dv1-61 〈assessed on 17 Jan 2005〉.

Fierke, K.M. (2006) 'Constructivism', T. Dunne, M. Kurki, Smith S. (eds) International Relations Theory: Discipline and Diversity, Oxford: Oxford University Press, pp. 166-184.

Gallie, W.B. (1956) 'Art as an essentially contested concept', Philosophical Quarterly, 97-114.

Giddens, A. (1979) Central Problems in Social Theory, Berkeley and Los Angeles: University of California Press. 
Giddens, A. (1984) The Constitution of Society, Berkeley and Los Angeles: University of California Press.

Hall, P. (1989) The Political Power of Economic Ideas, Princeton, NJ: Princeton University Press.

Hall, P. (1993) 'Policy paradigms, social learning, and the state: the case of economic policymaking in Britain', Comparative Politics 25(3): 275-296.

Hall, P. and Taylor, R. (1996) 'Political science and the three new institutionalisms', Political Studies 44(4): 936-957.

Jackson, R. (2005) The Global Convenant. Human Conduct in a World of States, Oxford: Oxford University Press.

Jenson, J. (2005) 'The European Union's citizenship regime: political and social rights in the era of new governance', Paper presentation at the workshop Contested Meanings: Democratic Practices and Principles Across Cultural Boundaries, Queen's University Belfast, 22-23 September 2005. Available online.

Jenson, J. (2007) 'The European Union's citizenship regime creating norms and building practices', Comparative European Politics 5(1): 35-51.

Joerges, C. and Neyer, J. (1997) 'From intergovernmental bargaining to deliberative political processes: the constitutionalisation of comitology', European Law Journal 3(3): 273-299.

Keohane, R.O. (1997) 'International relations and international law: two optics', Harvard International Law Journal 38(2): 487-502.

Kratochwil, F. and Ruggie, J.G. (1986) 'International organization: a state of the art on an art of the State', International Organization 40(4): 753-775.

Kratochwil, F.V. (1989) Rules, Norms, and Decisions. On the Conditions of Practical and Legal Reasoning in International Relations and Domestic Affairs, Cambridge: Cambridge University Press.

Lord, C. (2007) 'Contested Meanings, Democracy Assessment and the European Union', Comparative European Politics 5(1): 70-86.

McIlwain, C.H. (1939) Constitutionalism \& the Changing World; Collected Papers, Cambridge, UK: Cambridge University Press.

Milliken, J. (1999) 'The study of discourse in international relations: a critique of research and methods', European Journal of International Relations 5(2): 225-254.

Olsen, J.P. (2005) 'Unity and diversity — European style' Centre for European Studies', University of Oslo, unpublished manuscript.

Peters, B. (2005) 'Public Discourse, Identity and the Problem of Democratic Legitimacy', in E.O. Eriksen, (ed.) Making the European Polity, London: Routledge, pp. 84-123.

Pollak, J. (2007) 'Contested meanings of representation', Comparative European Politics 5(1): $87-103$

Puetter, U. (2007) 'Providing venues for contestation: the role of expert committees and informal dialogue among ministers in European Economic Policy Coordination', Comparative European Politics 5(1): 18-35.

Puntscher-Riekmann, S. (2007) 'In search of lost norms: is accountability the solution to the legitimacy problems of the European Union?' Comparative European Politics 5(1): 121-137.

Risse, T. (2000) 'Let's Argue!: Communicative action in world politics', in: International Organization 54(1): 1-39.

Rosenfeld, M. (1994) 'Modern Constitutionalism as Interplay Between Identity and Diversity', in M. Rosenfeld (ed.) Constitutionalism, Identity, Difference and Legitimacy: Theoretical Perspectives, Durham and London: Duke University Press, pp. 3-38.

Schimmelfennig, F. (2000) 'International socialization in the new Europe: rational action in an institutional environment', European Journal of International Relations 6(1): 109-139.

Skocpol, T. (1996) 'Bringing the State Back In', in B.E. Brown and R.C. Macridis (eds) Comparative Politics, Belmont et al.: Wadsworth Publishers. 
Somers, M. (1994) 'Rights, relationality, and membership: rethinking the making and meaning of citizenship', Law and Social Inquiry 19: 63-112.

Stone, A. (1994) 'What is a supranational constitution? An essay in international relations theory', Review of Politics 55: 444-471.

Taylor, C. (1993) 'To Follow a Rule ...', in C. Calhoun, E. LiPuma and M. Postone (eds.) Bourdieu: Critical Perspectives, Cambridge: Polity Press, pp. 45-60.

Tilly, C. (1975) 'Reflections On the History of State-Making', in T. Charles (ed.) The Formation of National States in Western Europe, Princeton: Princeton University Press, pp. 3-83.

Tully, J. (2002) 'The unfreedom of the moderns in comparison to their ideals of constitutionalism and democracy', Modern Law Review 65(2): 204-228.

Tully, J. (1995) Strange Multiplicity: Constitutionalism in an Age of Diversity, Cambridge and New York: Cambridge University Press.

Weiler, J.H.H. (1999) The Constitution of Europe. 'Do the New Clothes Have an Emperor?' and Other Essays on European integration, Cambridge and New York: Cambridge University Press.

Weiler, J.H.H. (ed.) (2002) The EU, The WTO and the NAFTA. Towards a Common Law of International Trade, Oxford: Oxford University Press.

Weiler, J.H.H. and Wind, M. (eds.) (2003) European Constitutionalism Beyond the State, Cambridge: Cambridge University Press.

Weldes, J. and Saco, D. (1996) 'Making state action possible: the United States and the discursive construction of 'The Cuban Problem', 1960-1994', Millennium 25(2): 361-395.

Wiener, A. (2006a) 'The invisible constitution, making normative meaning accountable for politics', Unpublished Manuscript, Belfast.

Wiener, A. (2006b) 'Soft Institutions', in A. von Bogdandy and J. Bast (eds.) Principles of European Constitutional Law, Oxford: Hart Publishing, pp. 419-449.

Wobbe, T. (2003) 'From protecting to promoting: evolving EU sex equality norms in an organisational field', European Law Journal 9(1): 88-108. 